\title{
Flocculation of cyanobacterial cells using coal fly ash modified chitosan
}

\author{
Yuting Yuan a, Honggang Zhang a, Gang Pan a, b, * \\ ${ }^{a}$ Research Center for Eco-Environmental Sciences, Chinese Academy of Sciences, Beijing, 100085, China \\ ${ }^{\mathrm{b}}$ School of Animal, Rural and Environmental Sciences, Nottingham Trent University, NG25 OQF, UK
}

\section{A R T I C L E I N F O}

\section{Article history:}

Received 30 April 2015

Received in revised form

21 November 2015

Accepted 2 December 2015

Available online 10 December 2015

\section{Keywords:}

Lake

Microcystis aeruginosa

Management

Geo-engineering

Coal fly ash

\begin{abstract}
A B S T R A C T
Harmful algal blooms (HABs) have increasingly occurred worldwide and pose serious threats to water environment safety. In this study, a compound flocculant (CFAL-Chitosan) was developed for HABs mitigation where chitosan was modified by coal fly ash leachate (CFAL). When using optimized dosage of CFAL-Chitosan flocculant, the zeta potential of Microcystis aeruginosa (M.A.) flocs stayed close to zero and algal removal efficiency plateaued over $90 \%$ in a wide dosage range from 3 to $6 \mathrm{mg} \mathrm{L}^{-1}$. For chitosan without CFAL, removal efficiency peaked at $3 \mathrm{mg} \mathrm{L}^{-1}$ with a maximum removal efficiency of $81 \%$, which quickly decreased as the dosage increased $\left(>3 \mathrm{mg} \mathrm{L}^{-1}\right)$ due to the fast reversal of zeta potential. This indicated that CFAL-Chitosan could maintain a better removal efficiency over a wide dosage range as a result of improved charge neutralization compared with the chitosan only treatment. The flocs of CFALChitosan were larger and denser than produced in the presence of chitosan without CFAL. However, excessive CFAL beyond the optimized dose inhibited M.A. removal due to hydrolysis and declining molecular weight of chitosan that weakened the bridging-netting properties, where surface charge reversal happened within a narrow dosage range and the removal-dosage curve became parabolic. The $\mathrm{pH}$ and metal residuals that were assumed to pose a threat to the aquatic environment were not significantly affected by adding optimized dosage of CFAL-Chitosan. The study provides a HABs control method using a cheap material of CFA. Further studies are needed to check the potential influence of leachable metals and persistent organic pollutants in CFA under a wide range of environmental condition.
\end{abstract}

๑) 2015 Elsevier Ltd. All rights reserved.

\section{Introduction}

Harmful algal blooms (HABs) and lake eutrophication have been intensively studied due to their threats to aquatic organisms, human health, coastal aesthetics and aquaculture (Gan et al., 2010; Thornton et al., 2013). Many approaches have been tested to control the nutrient fluxes to the receiving waterbodies including internal and external loading management (Huser, 2012; Sondergaard et al., 2002; Spears et al., 2013a). However, in cases where nutrient management is not economically feasible or the results obtained are unsatisfactory, additional strategies are needed to reinforce the recovery such as algae harvesting (Chen et al., 2012), filtrations (Yadidia et al., 1977), fish stocking (Jeppesen et al., 2012) and algicides (Garcia-Villada et al., 2004). Aluminum $(\mathrm{Al})$ and iron $(\mathrm{Fe})$ salts are widely used as geo-engineering materials

\footnotetext{
* Corresponding author. Research Center for Eco-Environmental Sciences, Chinese Academy of Sciences, Beijing, 100085, China.

E-mail address: gpan@rcees.ac.cn (G. Pan).
}

for P-sorption in eutrophic water. In addition, the $\mathrm{Al}$ and Fe salts can be used as a flocculant because their hydrolysis products can overcome the electrostatic stabilization of algal cells and promote flocs formation (Gonzalez-Torres et al., 2014). Effective precipitation is generally obtained by $\mathrm{Al}$ and Fe salts when a ballast is included (Pan et al., 2011a). Flocculation can be a welcome technique combined with nutrient control methods for eutrophication management, which can improve the water clarity and trigger submerged macrophyte restoration in shallow waters (Pei et al., 2014; Sun et al., 2013).

In recent years, efforts have been made to utilize natural polymers as flocculants such as chitosan (Li and Pan, 2015; 2013; Pan et al., 2011a, 2012, 2011b; Zou et al., 2006) which may be biodegradable and therefore represent a lower risk to human and environmental health (Wang et al., 2016). Chitosan can be used to modify the properties of local soils with respect to HABs removal through modification of charge neutralization and bridging-netting processes ( $\mathrm{Li}$ et al., 2015; Zou et al., 2006). However, the 
effectiveness of the modification can be confounded by various chemical components of the receiving waters, for example, 'folding' of the chitosan molecular chain in waters of high ionic strength and alkalinity (Pan et al., 2011a; Zou et al., 2005).

Commercial inorganic flocculants have been tested to assist the flocculation process of chitosan. Chitosan combined with poly aluminum chloride (PAC) can turn local soils into effective flocculants. Pan et al. (2011a) demonstrated this approach for the removal of cyanobacteria from suspensions using $10 \mathrm{mg} \mathrm{L}^{-1}$ PAC and $10 \mathrm{mg} \mathrm{L}{ }^{-1}$ chitosan. The PAC facilitates formation of small flocs which are linked by chitosan into flocs $40 \%$ larger than using PAC alone (Pan et al., 2011a). Coal fly ash (CFA) contains $25-30 \% \mathrm{Al}_{2} \mathrm{O}_{3}$ and $6-15 \% \mathrm{Fe}_{2} \mathrm{O}_{3}$ (Ahmaruzzaman, 2010), which may potentially enhance the flocculation properties of chitosan. Several studies report that CFA based flocculants prepared from acid or alkaline leachate of CFA are effective alternatives to commercial inorganic flocculants for water purification (Fan et al., 2005; Yan et al., 2012). Besides, CFA is a fine textured material and relatively widely available at the global scale which can potentially accelerate flocs sedimentation by adding frame and weight to the flocs. So far, few studies have assessed HABs removal using CFA and little is known about the effects of using chitosan and CFA on the flocculation of cyanobacteria.

In this study, $\mathrm{HCl}$ was used to extract $\mathrm{Al}$ and $\mathrm{Fe}$ from CFA. Chitosan was modified using CFA leachate (CFAL) to prepare a compound flocculant (CFAL-Chitosan) for M.A. flocculation. It is hypothesized that $\mathrm{Al}$ and $\mathrm{Fe}$ in CFAL can interact with chitosan and form a compound flocculant which may enhance the algal removal ability of chitosan. We evaluated the flocculation efficiency of the compound flocculant via dosage effect on removal efficiency, surface charge of algal flocs, floc size and stability. Fourier Transformed Infrared Spectroscopy (FT-IR) and molecular weight analysis were conducted to elucidate the flocculation mechanisms.

\section{Materials and methods}

\subsection{Algal species and culture}

Microcystis aeruginosa (M.A., FACHB-469) was obtained from the Freshwater Algae Culture Collection at the Institute of Hydrobiology Chinese Academy of Sciences (FACHB, Wuhan City, China), and cultured in BG11 medium under controlled conditions. Before autoclaving, the BG11 growth medium (Wyatt et al., 2012) was adjusted to $\mathrm{pH} 8.0$ using $0.5 \mathrm{~mol} \mathrm{~L}^{-1} \mathrm{NaOH}$ or $0.5 \mathrm{~mol} \mathrm{~L}^{-1} \mathrm{HCl}$. The algae batch culture with initial density of $1.23 \times 10^{5}$ cells $\mathrm{mL}^{-1}$ was held in a $10 \mathrm{~L}$ glass vessel and kept at $25 \pm 1{ }^{\circ} \mathrm{C}$ under $40-60 \mu \mathrm{mol} \mathrm{m} \mathrm{m}^{-2} \mathrm{~s}^{-1}$ of white fluorescent light on a $12 \mathrm{~h}$ light and $12 \mathrm{~h}$ dark regime in an illuminating incubator (LRH-250-G, Guangdong Medical AppratusCo.Ltd., China). Continuous aeration was supplied during the algae growth phase. M. aeruginosa cells under this condition were dispersed single cells (Li and Pan, 2013).

\subsection{CFA and CFAL-Chitosan}

CFA was collected from a power plant in Datong City (Shanxi province, China). The CFA was washed with deionized water three times, dried at $105{ }^{\circ} \mathrm{C}$, then sieved through 180 mesh before use ( $<90 \mu \mathrm{m}$, pre-treated CFA). The pre-treated CFA was characterized by X-ray fluorescence (XRF-1800, Shimadzu, Japan) and X-ray Diffraction (X'Pert Pro MPD X-ray Diffractometer, Philips, Netherlands). Toxicity Characterization Leaching Procedures (TCLP, see Supplementary Materials) were carried out to determine the metal mobility of pre-treated CFA (USEPA, 1994).

Pre-treated CFA was used in two ways in this study. Firstly, $100 \mathrm{mg} \mathrm{L}^{-1}$ of pre-treated CFA was utilized directly in the flocculation experiments and acted as ballast to assist sedimentation processes. Secondly, the leachate of pre-treated CFA (CFAL) was obtained using $\mathrm{HCl}$ and used for chitosan modification. The leaching protocol was optimized through a preliminary test and set as $2 \%$ $\mathrm{HCl}$ (in mass fraction), solid/liquid ratio of $1 \mathrm{~g}: 5 \mathrm{~mL}$, leaching time of $24 \mathrm{~h}$ under $25^{\circ} \mathrm{C}$ at an agitation rate of $180 \mathrm{rpm}$ in an oscillation incubator (HZQ-F160, HDL Electronic Technology Development Co., LTD, China). The CFAL was separated by filtration through a $0.45 \mu \mathrm{m}$ filter membrane. The metal concentrations in the CFAL were measured by ICP-OES (Optima 8300, PerkinElmer, USA).

The chitosan powder was purchased from Qingdao Yunzhou Biochemistry CO., LTD which originates from crab shells. Four CFALChitosan stock solutions were prepared, denoted as F-0, F-12, F-20 and F-40 and the treatments of CFAL-Chitosan stock solutions were shown in Table 1. The CFAL/Chitosan ratio for F-0, F-12, F-20 and F40 was $0 \mathrm{~mL}: 1 \mathrm{~g}, 12 \mathrm{~mL}: 1 \mathrm{~g}, 20 \mathrm{~mL}: 1 \mathrm{~g}$ and $40 \mathrm{~mL}: 1 \mathrm{~g}$, respectively. The CFAL-Chitosan stock solutions were freshly made and diluted ten times before use.

\subsection{Molecular weight and component analysis}

The molecular weight $\left(M_{v}\right)$ of CFAL-Chitosan was obtained from the intrinsic viscosity using Mark-Houwink-Sakurada equation reported before (Wang et al., 1991). The intrinsic viscosity was determined using $0.2 \mathrm{M}$ acetic acid/0.1 $\mathrm{M}$ sodium acetate with an Ubbelohde viscometer (Supplementary Materials, Intrinsic viscosity). Viscosity of the CFAL-Chitosan stock solutions was quantified using a rotational viscometer (NDJ-1, Shanghai Yueping Scientific Instrument co., LTD, China).

CFAL-Chitosan solutions were dried and mixed with $\mathrm{KBr}$ in a ratio of $1 \mathrm{mg}$ : $100 \mathrm{mg}$ for FT-IR analysis (Nicolet 8700, Thermo Fisher, USA). The total Al and Fe in CFAL-Chitosan solutions (F-12, F20, and F-40) were measured by ICP-OES (Optima 8300, PerkinElmer, USA). The Al bonded with chitosan (chitosan-Al) was separated by Al fraction procedure (Vanbenschoten and Edzwald, 1990) and quantified using ICP-OES (Optima 8300, PerkinElmer, USA). The free Fe was measured using polarograph (797 VA Computrace, Metrohm, Switzerland) and the Fe bonded with chitosan (chitosan-Fe) was calculated as the difference between free Fe and total Fe.

\subsection{Algae flocculation}

Flocculation experiments were set up in a jar test apparatus (ZR3-6, Zhongrun Water Industry Technology Development Co., Ltd., China). Algal cells in the mid-to late-exponential growth phase (Chen et al., 2004) were used and the cell concentration was $4.15-4.23 \times 10^{6}$ cells $\mathrm{mL}^{-1}$ at the start the flocculation experiments. The algal solution was adjusted to $\mathrm{pH} 8.0$ either by $0.5 \mathrm{~mol} \mathrm{~L}^{-1} \mathrm{NaOH}$ or $\mathrm{HCl}$ preceding the flocculation experiments and $200 \mathrm{~mL}$ of algal solution was transferred to a $300 \mathrm{~mL}$ beaker for flocculation. In the flocculation experiments, pre-treated CFA of $100 \mathrm{mg} \mathrm{L}^{-1}$ and different dosage of CFAL-Chitosan $(0.5,1.0,1.5,2.0$, $2.5,3.0,3.5,5.0$ and $6.0 \mathrm{mg} \mathrm{L}^{-1}$, in terms of chitosan concentration) were added to the algal solutions. The control was run by adding $100 \mathrm{mg} \mathrm{L}^{-1}$ of pre-treated CFA only. The stirring process was $200 \mathrm{rpm}$ for $1 \mathrm{~min}, 120 \mathrm{rpm}$ for $2 \mathrm{~min}, 40 \mathrm{rpm}$ for $10 \mathrm{~min}$ then the algal solutions were left static. After sedimentation for desired time intervals $(0,2,5,10,20,30,40,50$ and $60 \mathrm{~min})$, samples $(2 \mathrm{~mL})$ from $2 \mathrm{~cm}$ below the water surface were collected for cell counting. The removal rate was calculated as (initial cell concentration-sample cell concentration)/initial cell concentration $\times 100 \%$. The cells were firstly fixed with Lugol solution ( $1 \%$ final conc.) and enumerated using a hemocytometer using a microscope (Axioskop 2 mot plus, Carl ZEISS, Germany). The zeta potential was measured using 
Table 1

Treatments of CFAL-Chitosan stock solutions.

\begin{tabular}{|c|c|c|c|c|c|}
\hline No. & Chitosan powder (g) & CFAL $(\mathrm{mL})$ & Glacial acetic acid $(\mathrm{mL})$ & Deionized water (mL) & CFAL/Chitosan ratio (mL: $\mathrm{g}$ ) \\
\hline $\mathrm{F}-0$ & 0.5 & 0 & 0.5 & 99.5 & 0 \\
\hline F-12 & 0.5 & 6 & 0 & 94 & $12: 1$ \\
\hline $\mathrm{F}-20$ & 0.5 & 10 & 0 & 90 & $20: 1$ \\
\hline $\mathrm{F}-40$ & 0.5 & 20 & 0 & 80 & $40: 1$ \\
\hline
\end{tabular}

Zetasizer 2000 (Malvern Co. UK). The metal residuals of samples taken from the flocculated algal solutions after sedimentation for 30 min were quantified with ICP-OES (Optima 8300, PerkinElmer, USA) including $\mathrm{Al}, \mathrm{As}, \mathrm{Cr}, \mathrm{Cd}, \mathrm{Ba}$ and $\mathrm{Mn}$. The $\mathrm{pH}$ values of the algal solutions were also recorded before and after flocculation using a pH meter (PHSJ-4A, Shanghai REX Instrument Factory, China). The floc growth during the stirring process was monitored by a laser particle size analyzer (Mastersizer 2000, Malvern Co. UK). Samples were sent into the analyzer and back to the jar by a peristaltic pump (BT00-300M, Baoding Longer Precision Pump Co. Ltd., China) with a flow rate of $35 \mathrm{~mL} \mathrm{~min}{ }^{-1}$. The flocculation tests were operated in triplicate and the results were presented as mean values.

\subsection{Floc stability}

Different shear force was applied to the flocs following the slow stirring process by increasing the stirring speed to 75, 100, 150, 200 and $250 \mathrm{rpm}$ for another $20 \mathrm{~min}$. The corresponding velocity gradient $(\mathrm{G})$ values were $28.1,41.3,71.3,105.0$ and $141.7 \mathrm{~s}^{-1}$, respectively. The dynamic flocs sizes were recorded as $d_{0.5}$ during the stirring process. Referring to the empirical equation (Shi et al., 2016), the broken floc size was plotted against the average velocity gradient in a $\log -\log$ scale and the slope of the curve $(\gamma)$ is the main factor to quantify floc stability.

$\log d=\log C-\gamma \log G$

where $d$ is the median floc diameter $\left(d_{0.5}\right)$ after breakage, $\mu \mathrm{m} ; C$ is the floc strength co-efficient; $\gamma$ is the stable floc exponent and $G$ is the average velocity gradient, $\mathrm{s}^{-1}$.

\section{Results}

\subsection{Characteristics of CFA and CFAL-Chitosan}

The pre-treated CFA used in this study mainly consisted of $\mathrm{SiO}_{2}$, $\mathrm{Al}_{2} \mathrm{O}_{3}$, and $\mathrm{Fe}_{2} \mathrm{O}_{3}$ (Table S1). XRD analysis showed the presence of quartz, mullite, hematite and corundum (Fig. S1). The metal ions leached from the pre-treated CFA were more evident under acid conditions ( $\mathrm{pH}=2.88$ ) compared with $\mathrm{pH} 7.5$ (Table 2). The total Al

Table 2

The concentration of metal ions leached from the pre-treated CFA in TCLP test (mg $\left.\mathrm{L}^{-1}\right)$.

\begin{tabular}{llll}
\hline \multirow{2}{*}{ Metals $^{\mathrm{a}}$} & \multicolumn{2}{l}{ Concentration of metal } \\
\cline { 2 - 4 } & $\mathrm{pH}=2.88^{\mathrm{b}}$ & $\mathrm{pH}=4.93^{\mathrm{c}}$ & $\mathrm{pH}=7.50^{\mathrm{d}}$ \\
\hline Aluminum & 17.6 & 0.3 & 0.3 \\
Barium & 4.5 & 2.1 & 0.2 \\
Iron & 0.3 & - & - \\
Magnesium & 58.6 & 35.1 & 1.0 \\
Manganese & 1.54 & 0.6 & - \\
\hline a Elements below the detection limit $\left(<0.01 \mathrm{mg} \mathrm{L}^{-1}\right): \mathrm{As}, \mathrm{Be}, \mathrm{Bi}, \mathrm{Cd}, \mathrm{Co}, \mathrm{Cr}, \mathrm{Cu}, \mathrm{Ni}$, \\
Sb, Sn, Ti, V, Zn, Zr, Pb. & & \\
b Acetic acid solution. & & \\
c Acetic acid solution. & & \\
d Deionized water.
\end{tabular}

and $\mathrm{Fe}$ in CFAL-Chitosan increased with the increasing ratio of CFAL/Chitosan and the chitosan-Al and -Fe were detected in CFALChitosan (Fig. 1).

The molecular weight $\left(M_{v}\right)$ of CFAL-Chitosan was calculated from the intrinsic viscosity. The $M_{v}$ of chitosan without CFAL (CFAL/ Chitosan 0:1) was $682 \mathrm{kDa}$. Both $M_{v}$ and viscosity of CFAL-Chitosan decreased as CFAL/Chitosan ratio increased. When CFAL/Chitosan ratio was $40: 1$, the $M_{v}$ and viscosity decreased $21.3 \%$ and $63.5 \%$ respectively compared to chitosan without CFAL.

For chitosan powder and chitosan without CFAL (CFAL/Chitosan $0: 1$, Fig. 3), a broad adsorption band around $3417 \mathrm{~cm}^{-1}$ corresponded to the overlap of $\mathrm{OH}$ and $\mathrm{NH}_{2}$ stretching vibration and the peak at $2900 \mathrm{~cm}^{-1}$ was attributed to the stretching of $\mathrm{CH}$ (Ng et al., 2012). The band around $1650 \mathrm{~cm}^{-1}$ referred to the amide I group, and the peak at 1596 and $1561 \mathrm{~cm}^{-1}$ was the band of amide II $(\mathrm{Ng}$ et al., 2012). The aliphatic $\mathrm{OH}$ band, acetal and glycosidic linkage were associated with peaks at 1423, 1154-1030 and $898 \mathrm{~cm}^{-1}$, respectively (Ng et al., 2012; Wang et al., 2011). The spectrum of chitosan with CFAL (F-12, F-20, and F-40 in Fig. 3) showed different characteristics from chitosan without CFAL. The band at $3417 \mathrm{~cm}^{-1}$ shifted to 3241,3395 and $3394 \mathrm{~cm}^{-1}$ and the amide I group shifted from $1642 \mathrm{~cm}^{-1}$ to 1625,1636 and $1635 \mathrm{~cm}^{-1}$ for F-12, F-20 and F40 , respectively. The band of amide II and aliphatic $\mathrm{OH}$ extinguished, however, a new band emerged around $1500 \mathrm{~cm}^{-1}$.

\subsection{Dosage effect of CFAL-Chitosan}

For chitosan without CFAL, the M.A. removal reached a peak of $81.6 \pm 1.9 \%$ at $3 \mathrm{mg} \mathrm{L}^{-1}$ then decreased significantly when chitosan dosage exceeded $3 \mathrm{mg} \mathrm{L}^{-1}$ (F-0 in Fig. 4). When the CFAL/Chitosan ratio was $12: 1$, the maximum removal rate plateaued at $98.2 \pm 1.5 \%$ at $3 \mathrm{mg} \mathrm{L}^{-1}$ and remained stable until the dosage increased to $6 \mathrm{mg} \mathrm{L}^{-1}$ (F-12 in Fig. 4). A rate of $95.0 \pm 1.5 \%$ was found at $3.5 \mathrm{mg} \mathrm{L}^{-1}$ for CFAL/Chitosan ratio of 20:1 (F-20 in Fig. 4). When the CFAL/Chitosan ratio further increased to 40:1 (F-40), the algae removal reached to a peak of $76.5 \pm 2.8 \%$ at $2 \mathrm{mg} \mathrm{L}^{-1}$, which was quickly reduced beyond the optimal dosage of $2 \mathrm{mg} \mathrm{L}^{-1}$ (F-40 in Fig. 4). The zeta potential of M.A. flocs increased as CFAL-Chitosan was added to the algal solution. For F- 0 and F-40, the charge of M.A. flocs reversed at $5 \mathrm{mg} \mathrm{L}^{-1}$ and $3.5 \mathrm{mg} \mathrm{L}^{-1}$, respectively. While the charge reversals were not observed for both F-12 and F-20 bellow the dosage of $6 \mathrm{mg} \mathrm{L}^{-1}$. At the optimized dosage for F-0, F$12, \mathrm{~F}-20$ and F-40, the concentrations of remaining cells at the end of the experiments were $(77.3 \pm 8.0) \times 10^{4},(7.5 \pm 6.2) \times 10^{4}$, $(21.0 \pm 6.3) \times 10^{4}$ and $(97.8 \pm 11.6) \times 10^{4}$ cells $\mathrm{mL}^{-1}$, respectively. According to the dosage-efficiency curves, the CFAL-Chitosan dosage was set as $3 \mathrm{mg} \mathrm{L}^{-1}$ for the floc growth, flocculation kinetic and floc stability experiments.

\subsection{Floc growth and flocculation kinetics}

Using pre-treated CFA up to $100 \mathrm{mg} \mathrm{L}^{-1}$ did not promote M.A. aggregation and the removal efficiency was zero (Figs. 5 and 6). For chitosan without CFAL, the growth of flocs plateaued at $12 \mathrm{~min}$ with floc size of approx. $560 \mu \mathrm{m}$ (F-0 in Fig. 5). After sedimentation for $5 \mathrm{~min}$, the removal rate reached $79.7 \%$ and did not change as the 

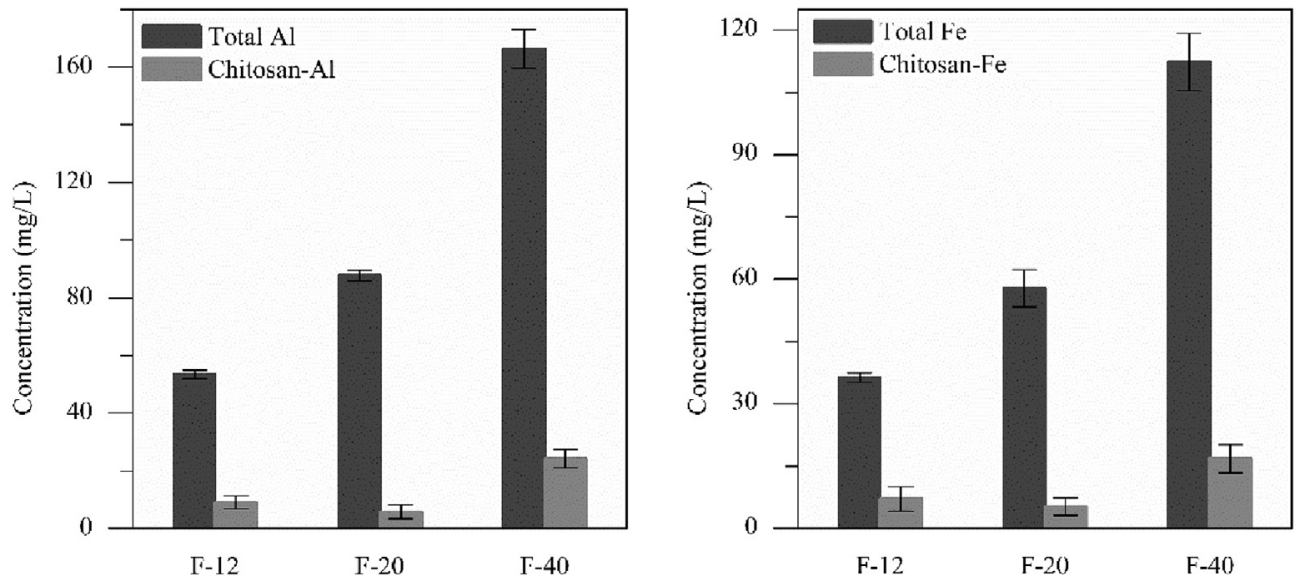

Fig. 1. The Al and Fe in CFAL-Chitosan, F-12: CFAL/Chitosan ratio 12:1, F-20: CFAL/Chitosan ratio 20:1, F-40: CFAL/Chitosan ratio 40:1.

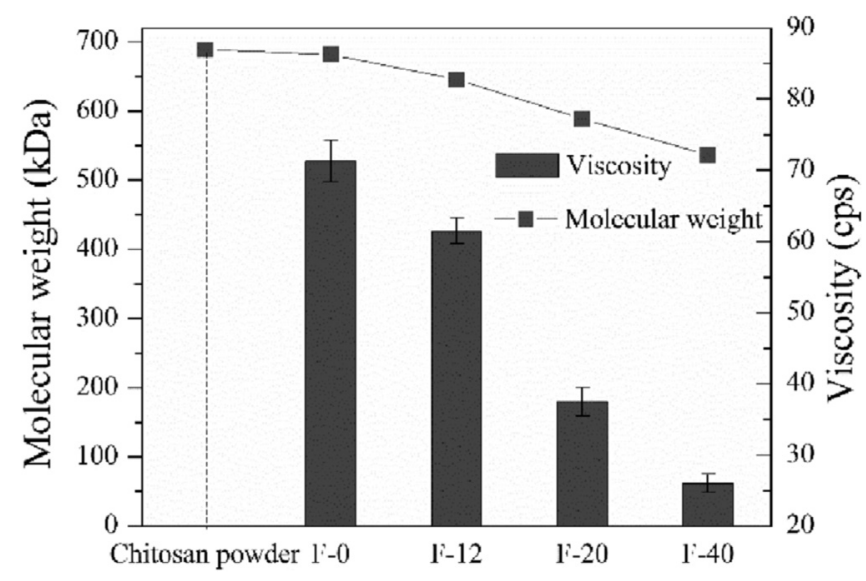

Fig. 2. The molecular weight ( $\mathrm{kDa}$ ) and viscosity (cps) of chitosan powder and CFALChitosan, F-0: CFAL/Chitosan ratio 0:1, F-12: CFAL/Chitosan ratio 12:1, F-20: CFAL/ Chitosan ratio 20:1, F-40: CFAL/Chitosan ratio 40:1.

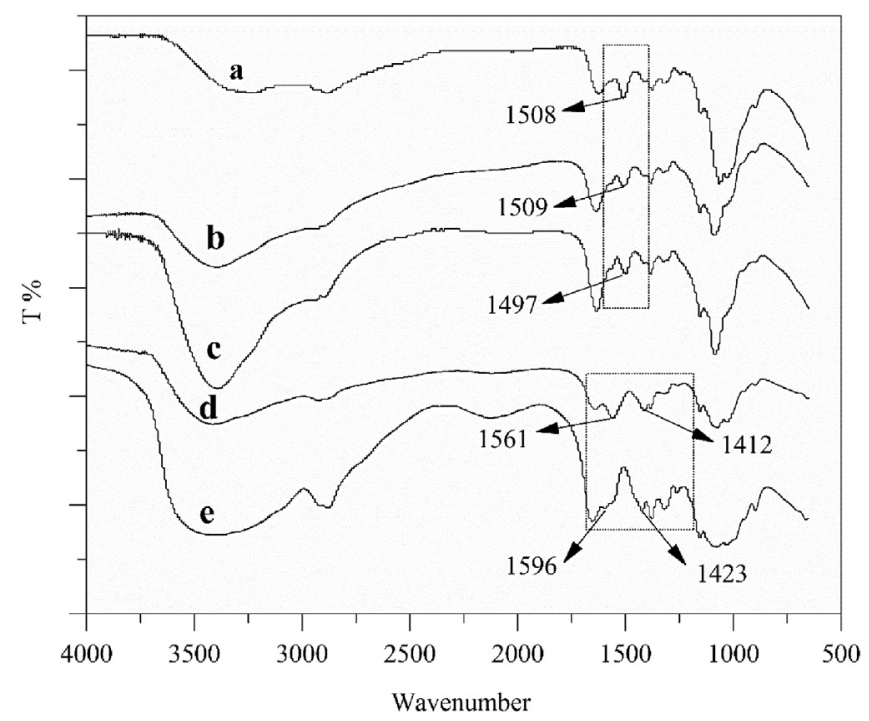

Fig. 3. The FT-IR spectra of chitosan powder and CFAL-Chitosan, a: F-12 CFAL/Chitosan 12:1, b: F-20 CFAL/Chitosan 20:1, c: F-40 CFAL/Chitosan 40:1, d: F-0 CFAL/Chitosan 0:1, e: chitosan powder. experiment proceeded for the F-0 treatment (F-0 in Fig. 6). When the CFAL/Chitosan was $12: 1$ and $20: 1$, the floc size increased to $750 \mu \mathrm{m}$ (F-12 \& F-20 in Fig. 5), but F-12 exhibited a faster growth rate. The removal efficiency of $\mathrm{F}-12$ reached $97.2 \%$ within 2 min and remained stable, while $87.5 \%$ of algal cells were removed for $\mathrm{F}-20$ after sedimentation for 60 min (Fig. 6). When the CFAL/Chitosan was $40: 1$, the floc size $(380 \mu \mathrm{m})$ decreased compared to F-0, F-12 and $\mathrm{F}-20$ and a lower removal rate of $72.8 \%$ was achieved at $60 \mathrm{~min}$ (Figs. 5 and 6).

\subsection{Floc stability}

The stability of algal flocs at $3 \mathrm{mg} \mathrm{L}^{-1}$ CFAL-Chitosan was tested by measuring the floc size changes after applying a shear force (Shi et al., 2016). The stable floc exponent $(\gamma)$ is a quantitative measurement of floc stability. When the CFAL/Chitosan ratio was 12 , the $\gamma$ of flocs was 0.39 , lower than chitosan without CFAL (0.49) indicating that the floc stability was improved (Fig. 7). However, when excessive CFAL was added (F40), the floc stability decreased compared to CFAL-Chitosan (F-12, Fig. 7).

\section{Discussion}

\subsection{M.A. removal by chitosan without CFAL}

The zeta potential of M.A. flocs was $-34.8 \mathrm{mv}$ when pre-treated CFA alone (100 $\mathrm{mg} \mathrm{L}^{-1}$ ) was added and the algal cells were not removed from suspension due to the electrostatic repulsion (Figs. 4 and 6). When chitosan without CFAL (CFAL/Chitosan ratio $=0: 1$ ) was added at $3 \mathrm{mg} \mathrm{L}^{-1}$, the removal rate reached a peak of $81.4 \pm 1.9 \%$ and the zeta potential increased from -34.8 to -15.4 $\mathrm{mv}$, indicating the electrostatic repulsion was reduced, which may be due to attraction between the amine groups of chitosan and algal cells (F-0 in Fig. 4). Chitosan is a linear biopolymer with high molecular weight (682 kDa, Fig. 2) and has a long polymer chain structure (Li et al., 2013). The flocs of large size were formed $(560 \mu \mathrm{m})$ through electrostatic attraction and bridging-netting function by the long polymer chain of chitosan (F-0 in Fig. 5). However, $18.6 \%$ of algal cells were not removed since the surface charge of algal flocs were not sufficiently neutralized with zeta potential far below zero $(-15.4 \mathrm{mv})$ at the optimized dosage of chitosan without CFAL ( $3 \mathrm{mg} \mathrm{L}^{-1}$ ) (Li et al., 2015). Besides, M.A. removal was not stable and declined significantly at $5 \mathrm{mg} \mathrm{L}^{-1}$ due to reversal of the zeta potential $(+3.4 \mathrm{mv})$ and re-stabilization of algal flocs (F-0 in Fig. 4). 

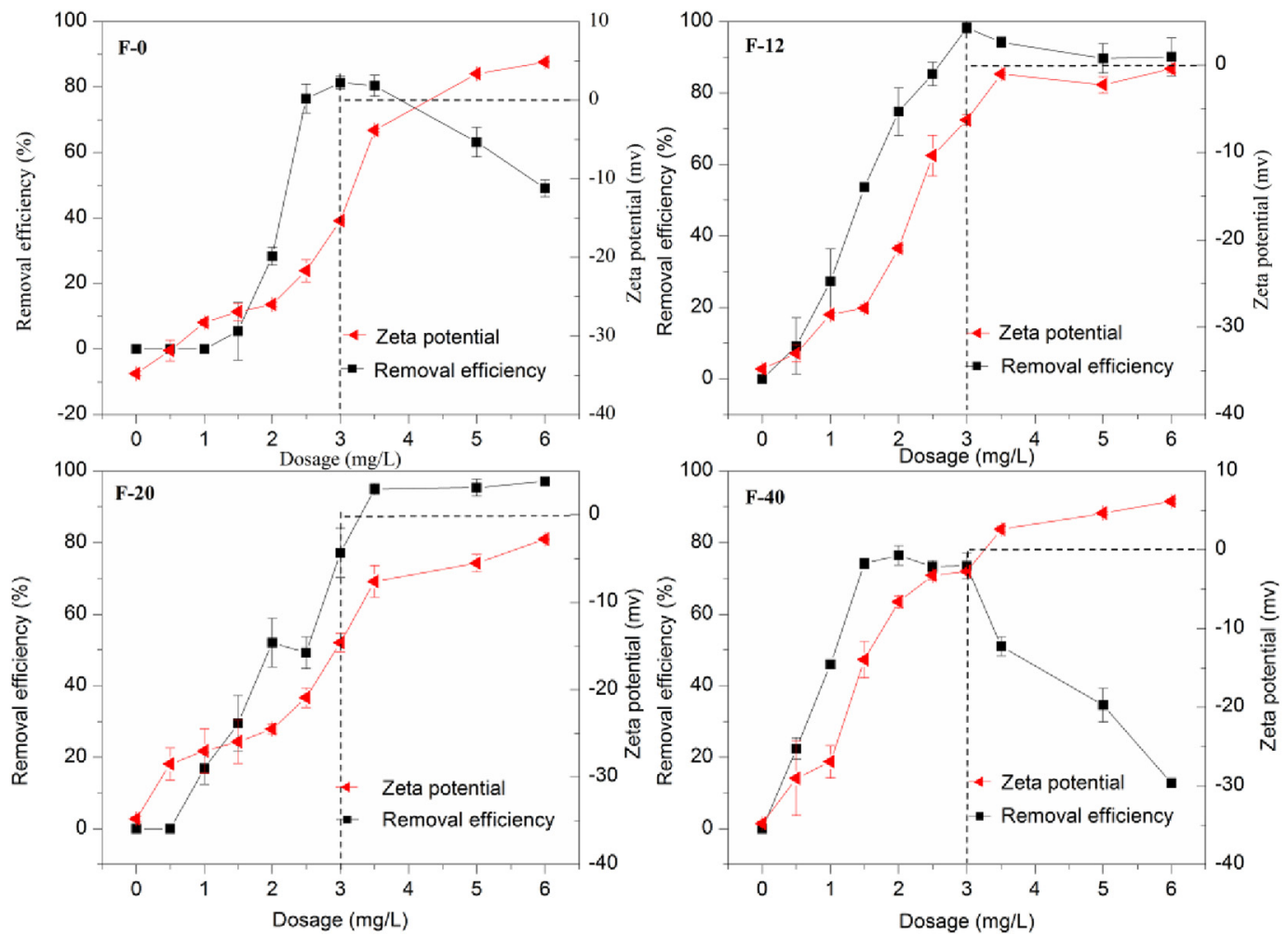

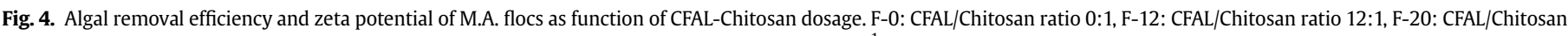
ratio 20:1, F-40: CFAL/Chitosan ratio 40:1, initial $\mathrm{pH} 8.0$, pre-treated CFA concentration $100 \mathrm{mg} \mathrm{L}^{-1}$.

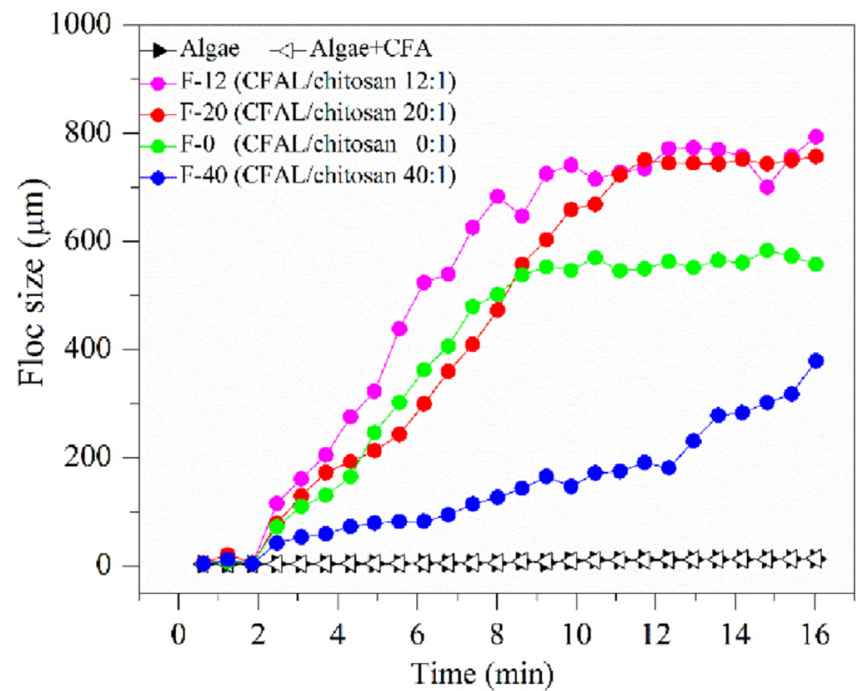

Fig. 5. The dynamic floc size of M.A. cells after addition of $3 \mathrm{mg} \mathrm{L}^{-1}$ CFAL-Chitosan, initial $\mathrm{pH}$ 8.0, pre-treated CFA concentration $100 \mathrm{mg} \mathrm{L}^{-1}, \mathrm{~F}-0$ : CFAL/Chitosan ratio 0:1, F-12: CFAL/Chitosan ratio 12:1, F-20: CFAL/Chitosan ratio 20:1, F-40: CFAL/Chitosan ratio 40:1.

\subsection{M.A. removal by chitosan with CFAL}

Although CFAL alone was not effective in M.A. removal (Table S2), it enhanced M.A. flocculation of chitosan (F-12, F-20, Fig. 4). The removal rate of F-12 and F-20 reached over $95 \%$ at 3 and $3.5 \mathrm{mg} \mathrm{L}^{-1}$, respectively and was higher than chitosan without CFAL (Fig. 4). Moreover, the flocs of F-12 were $34 \%$ larger and more stable and sunk faster together with a ballast compared with the chitosan

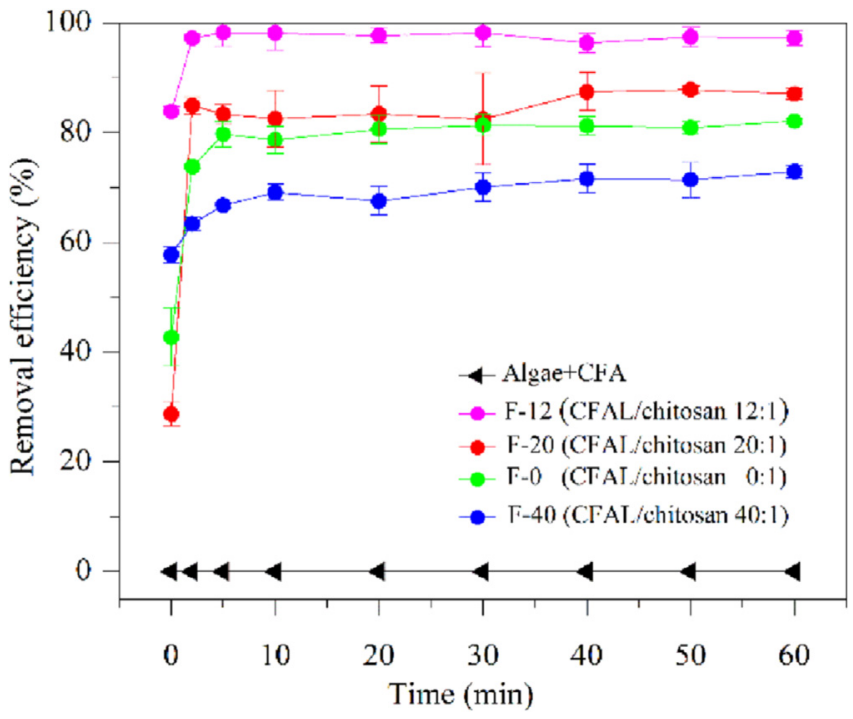

Fig. 6. The flocculation kinetics of M.A. cells after addition of $3 \mathrm{mg} \mathrm{L}^{-1}$ CFAL-Chitosan, initial $\mathrm{pH}$ 8.0, and pre-treated CFA concentration $100 \mathrm{mg} \mathrm{L}^{-1}, \mathrm{~F}-0$ : CFAL/Chitosan ratio 0:1, F-12: CFAL/Chitosan ratio 12:1, F-20: CFAL/Chitosan ratio 20:1, F-40: CFAL/Chitosan ratio 40:1.

only treatment at dosage of $3 \mathrm{mg} \mathrm{L}^{-1}$ (Figs. 5-7). When the flocculant dosage was beyond the optimized dosage, i.e. 3 and $3.5 \mathrm{mg} \mathrm{L}^{-1}$ for $\mathrm{F}-12$ and $\mathrm{F}-20$, respectively, the zeta potential of algal flocs using chitosan with CFAL (F-12, F-20) stayed near zero and algal removal efficiency plateaued over $90 \%$ and $95 \%$, respectively. While for chitosan without CFAL (F-0), the removal efficiency was significantly lower compared to CFAL-Chitosan (F-12, F-20) due to 


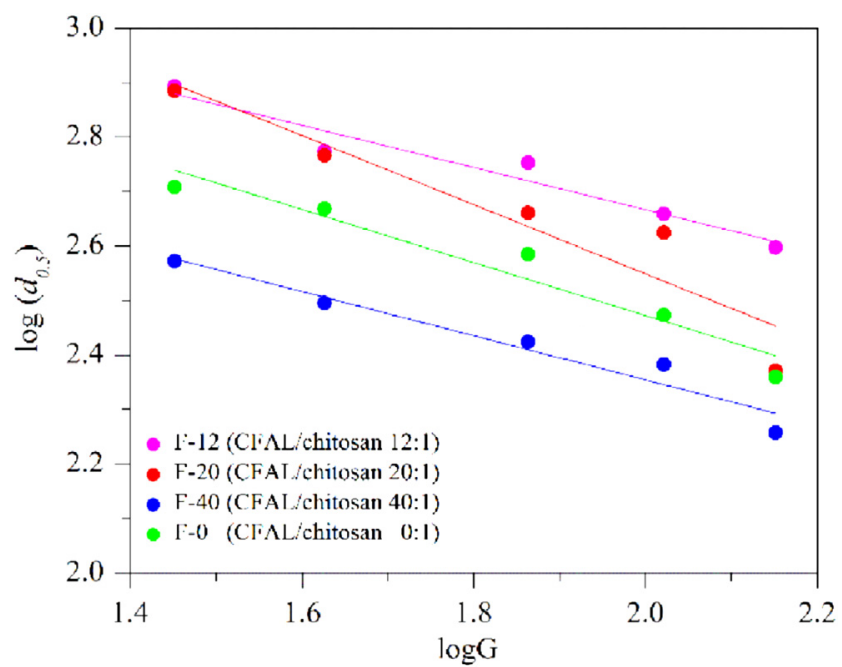

Fig. 7. Floc stability plots of CFAL-Chitosan at $3 \mathrm{mg} \mathrm{L}^{-1}$ (pre-treated CFA dosage, $100 \mathrm{mg} \mathrm{L}^{-1}$, initial $\mathrm{pH}=8.0$, Shear time, $16 \mathrm{~min}$ ). F-0: CFAL/Chitosan ratio $0: 1, \mathrm{~F}-12$ : CFAL/Chitosan ratio 12:1, F-20: CFAL/Chitosan ratio 20:1, F-40: CFAL/Chitosan ratio 40:1.

the fast reversal of zeta potential at dosage beyond $3 \mathrm{mg} \mathrm{L}^{-1}$ (5-6 $\mathrm{mg} \mathrm{L}^{-1}$, Fig. 4). This indicated that CFAL-Chitosan can maintain a better algal removal rate over a wide dosage range due to improved charge neutralization. The component analysis confirmed the formation of chitosan-Al and -Fe in the prepared flocculants (Fig. 1). Compared with the FT-IR spectrum of chitosan without CFAL (CFAL/Chitosan ratio $=0: 1$ ), the amide II and aliphatic OH groups disappeared when chitosan was modified by CFAL (F-12, F-20, F-40 in Fig. 3). A distinct band emerged at $1500 \mathrm{~cm}^{-1}$ which could potentially be the characteristic of $\mathrm{Al}-\mathrm{NH}_{2}$ or $\mathrm{Fe}-\mathrm{NH}_{2}$ (Himmel et al., 2000; Wang et al., 2011). It indicated that the $\mathrm{OH}$ and $\mathrm{NH}_{2}$ of chitosan might chelate with $\mathrm{Al}$ and Fe in CFAL. The free $\mathrm{Al} / \mathrm{Fe}$ in CFAL-Chitosan may also contribute to enhancing the charge neutralization of chitosan and it requires further studies to explore the functions of chitosan-Al and -Fe.

For F-12, when the dosage was higher than $3 \mathrm{mg} \mathrm{L}^{-1}$, the electrostatic repulsion between M.A. flocs was low and M.A. removal remained over $90 \%$ (Fig. 4). However, when the CFAL/Chitosan ratio increased to 40:1, a sharp decline of algal removal occurred again at $3.5 \mathrm{mg} \mathrm{L}^{-1}$ due to reversed charge $(+2.6 \mathrm{mv})$. This indicated that excessively increasing CFAL/Chitosan ratio may result in faster reversal of algal charge and narrow the dosage range of effective algal removal. Effective M.A. flocculation was generally obtained at the dosage where the zeta potential of algal flocs was near zero. In this study, a moderate amount of CFAL (CFAL/Chitosan ratio 12:1) optimized the charge neutralization of chitosan and a wide dosage range for effective M.A. removal was obtained. At the optimized dosage of F-12, the concentration of cells remaining in the flocculated algal solution was $(7.5 \pm 6.2) \times 10^{4}$ cells $\mathrm{mL}^{-1}$, which was lower compared to the starting concentration $\left(4.15-4.23 \times 10^{6}\right.$ cells $\left.\mathrm{mL}^{-1}\right)$, but higher than the WHO recommendations $\left(2.0 \times 10^{4}\right.$ cells $\left.\mathrm{mL}^{-1}\right)$ for safe recreational waters (2003). In addition, the $\mathrm{pH}$ and metal residuals in algal solution before and after flocculation were unaffected by the test conditions in this study (Table S3).

The long chain structure of chitosan is largely responsible for the bridging-netting property which is positively related to the molecular weight (Li et al., 2013). When chitosan was modified by CFAL, the molecular weight $\left(M_{v}\right)$ of CFAL-Chitosan decreased (Fig. 2), indicating that the long chain structure of chitosan was adversely influenced and the bridging-netting ability was weakened by the over dosed CFAL. The $\mathrm{HCl}$ in CFAL may trigger the hydrolysis of chitosan molecules (Vårum et al., 2001). The floc size and flocs sedimentation of CFAL-Chitosan decreased when CFAL/ Chitosan ratio was $40: 1$, which supported a weaker bridgingnetting effect (Figs. 5 and 6 ). $\mathrm{HCl}$ is a frequently used extracting agent to prepare CFA based flocculants (Choo et al., 2014; Yan et al., 2012). However, concentrated $\mathrm{HCl}$ can result in the hydrolysis and reduction of molecular weight of chitosan, which inhibits the bridging-netting ability (Fig. 2). During the preparation of CFALChitosan, CFAL was diluted suggesting that the acid concentration used for CFA leaching can be reduced in practical application to alleviate the negative impacts on chitosan structure. There was a balance between the charge neutralization enhancement and structural influence of chitosan when modified by CFAL. It is likely that the M.A. removal can be potentially improved by screening mild extracting agents which not only extract $\mathrm{Al} / \mathrm{Fe}$ but also maintain the chitosan structure.

\subsection{Considerations of environmental risk associated with the approach}

Spears et al. (2013b) recommended careful consideration of the environmental risks associated with the use of industrial waste materials for the management of eutrophication symptoms in natural freshwater ecosystems. In this study, both pre-treated CFA and CFAL were utilized. Since the heavy metal ions such as Mn and Ba (Table S4) were detected in CFAL, the dosage of CFAL used in chitosan modification should be carefully optimized which was closely related to the amount of heavy metals ions introduced to the algal solution. Although the metal mobility in pre-treated CFA under alkaline conditions was low $(\mathrm{pH}=7.50)$ and within the allowable limits of USEPA standard for hazardous materials (1994), it may be a concern under acid conditions (Table 2). CFA may also contain persistent organic pollutants such as PAH and dioxin. The availability of these pollutants in CFA under wide environmental conditions needs further investigation. Moreover, CFA composition varies from coal types and combustion processes. CFA screening is essential before it can be used for HABs control.

\subsection{Scope of the approach for environmental management}

In the past decades, efforts to reduce cyanobacteria concentrations in lakes have focused on the reduction of catchment $P$ loading such as wastewater treatment and agriculture, and internal loading such as adding P-sorption materials and sediment dredging (Jeppesen et al., 2005; Spears et al., 2016). However, many additional physical, chemical and biological methods have been developed to reinforce recovery when the obtained results are unsatisfactory. Flocculation can quickly remove the suspended algal cells down to the sediments and improve water transparency which provides favorable conditions for photosynthesis and/or submerged macrophytes restoration in shallow waters (Bakker et al., 2013). Chitosan as an algal flocculant may have positive side-effects such as killing the settled algal cells since the breakdown products of chitosan are suspected to have antibacterial activities (Wisniewska-Wrona et al., 2007) but the latter requires further studies. In addition, using pre-treated CFA as an alternative ballast to replace local soil has several advantages in some cases. Firstly, CFA is produced in large quantities and is convenient to access in industrialized and urban areas. In contrast, local soils may be difficult to source in urban areas or may be prohibited within urban planning legislation. Secondly, the CFA is a fine textured material which easily collides with algal cells (Han and Kim, 2001). We expect the pre-treatment of CFA to be minimal in comparison to other modified materials and the approach may provide added 
value in terms of providing a use for a current industrial waste material. However, local planning considerations and environmental risk assessments should be conducted for all materials proposed for use in the environment in this way. Although the controlled lab experiments suggested the possibility of HABs mitigation using CFAL-Chitosan, the control of adverse effects associated with algal flocculation is complex and the use of other agents to mitigate secondary effects should be appropriately assessed.

In this study, at the optimized dosage of CFAL-Chitosan, the calculated Al dosage was $0.02 \mathrm{mg} \mathrm{L}^{-1}\left(\mathrm{~F}-12,3 \mathrm{mg} \mathrm{L}^{-1}\right)$ and significantly lower compared to the effective dosage reported in other studies (Gonzalez-Torres et al., 2014; Paul et al., 2008). Introducing a small amount of CFAL can improve the flocculation efficiency of chitosan. Table S5 estimated the cost of several methods for HABs control. To achieve a cyanobacteria removal rate of over $90 \%$, the cost of CFAL-Chitosan is $0.07 \mathrm{US} \$ / \mathrm{m}^{3}$, which is lower than the PACChitosan (0.23 US\$m ${ }^{-3}$ ) and Moringa oleifera-Chitosan (MO-Chitosan, 5.19 US\$ $\mathrm{m}^{-3}$ ) (Li and Pan, 2013; Pan et al., 2011a). In further studies, it is possible to reduce the cost by screening cheaper biopolymers such as cationic starch and larch tannin (Shi et al., 2016; Wang et al., 2013).

\section{Conclusion}

In this study, we developed a compound flocculant using coal fly ash leachate (CFAL) modified chitosan for M. aeruginosa (M.A.) flocculation. It was found that the CFAL enhanced the flocculation ability of chitosan for M.A. removal at CFAL/Chitosan ratio of 12:1 and a good algal removal rate remained across a wide dosage range due to the improvement of charge neutralization. The algal flocs of CFAL-Chitosan were larger and denser than produced in the presence of chitosan without CFAL. However, when the CFAL/Chitosan ratio was beyond the optimal, a surplus of CFAL inhibited the M.A. removal due to hydrolysis resulting in a decline in molecular weight of chitosan which impaired the bridging-netting properties. New mild extracting methods should be studied in the future which not only extract Al/Fe in CFA but also maintain the chitosan structure at the same time. CFA combined with CFAL-Chitosan can be a possible economical way for HABs mitigation owing to its availability and ease of pre-treatment. Further studies are needed to ensure leachable metals and persistent organic pollutants (pops) in CFA pose no threat to human or environmental health across a wide range of environmental conditions.

\section{Acknowledgments}

The research was supported by the Strategic Priority Research Program of CAS (XDA09030203), the Science Promotion Program of RCEES, CAS (YSW2013B05), and National Natural Science Foundation of China (41401551).

\section{Appendix A. Supplementary data}

Supplementary data related to this article can be found at http:// dx.doi.org/10.1016/j.watres.2015.12.003.

\section{References}

Ahmaruzzaman, M., 2010. A review on the utilization of fly ash. Prog. Energy Combust. Sci. 36 (3), 327-363.

Bakker, E.S., Sarneel, J.M., Gulati, R.D., Liu, Z., van Donk, E., 2013. Restoring macrophyte diversity in shallow temperate lakes: biotic versus abiotic constraints. Hydrobiologia 710 (1), 23-37.

Chen, H., Pan, G., Zhang, M.M., 2004. Effect of growth phase on the flocculation of algal cells using clays. Environ. Sci. 06, 85-88 (in Chinese).
Chen, W., Jia, Y., Li, E., Zhao, S., Zhou, Q., Liu, L., Song, L., 2012. Soil-based treatments of mechanically collected cyanobacterial blooms from Lake Taihu: efficiencies and potential risks. Environ. Sci. Technol. 46 (24), 13370-13376.

Choo, T.K., Song, Y., Zhang, L., Selomulya, C., Zhang, L., 2014. Mechanisms underpinning the Mobilization of iron and Magnesium cations from Victorian Brown coal fly ash. Energy \& Fuels 28 (6), 4051-4061.

Fan, M.H., Brown, R.C., Wheelock, T.D., Cooper, A.T., Nomura, M., Zhuang, Y.H., 2005. Production of a complex coagulant from fly ash. Chem. Eng. J. 106 (3), 269-277.

Gan, N.Q., Sun, X.Y., Song, L.R., 2010. Activation of Nrf2 by Microcystin-LR provides advantages for Liver Cancer cell growth. Chem. Res. Toxicol. 23 (9), 1477-1484.

Garcia-Villada, L., Rico, M., Altamirano, M., Sanchez-Martin, L., Lopez-Rodas, V., Costas, E., 2004. Occurrence of copper resistant mutants in the toxic cyanobacteria Microcystis aeruginosa: characterisation and future implications in the use of copper sulphate as algaecide. Water Res. 38 (8), 2207-2213.

Gonzalez-Torres, A., Putnam, J., Jefferson, B., Stuetz, R.M., Henderson, R.K., 2014. Examination of the physical properties of microcystis aeruginosa flocs produced on coagulation with metal salts. Water Res. 60, 197-209.

Han, M.Y., Kim, W., 2001. A theoretical consideration of algae removal with clays. Microchem. J. 68 (2-3), 157-161.

Himmel, H.J., Downs, A.J., Greene, T.M., 2000. Thermal and photochemical reactions of aluminum, gallium, and indium atoms (M) in the presence of ammonia: generation and characterization of the species M center dot NH3, HMNH2, MNH2, and H2MNH2. J. Am. Chem. Soc. 122 (40), 9793-9807.

Huser, B.J., 2012. Variability in phosphorus binding by aluminum in alum treated lakes explained by lake morphology and aluminum dose. Water Res. 46 (15), 4697-4704.

Jeppesen, E., Søndergaard, M., Jensen, J.P., Havens, K., Anneville, O., Carvalho, L., Coveney, M.F., Deneke, R., Dokulil, M.T., Foy, B., Gerdeaux, D., Hampton, S.E., Hilt, S., Kangur, K., Kohler, J., Lammens, E.H.H.R., Lauridsen, T.L., Manca, M., Miracle, M.R., Moss, B., Noges, P., Persson, G., Phillips, G., Portielje, R., Romo, S., Schelske, C.L., Straile, D., Tatrai, I., Willen, E., Winder, M., 2005. Lake responses to reduced nutrient loading - an analysis of contemporary long-term data from 35 case studies. Freshw. Biol. 50, 1747-1771.

Jeppesen, E., Sondergaard, M., Lauridsen, T.L., Davidson, T.A., Liu, Z., Mazzeo, N., Trochine, C., Ozkan, K., Jensen, H.S., Trolle, D., Starling, F., Lazzaro, X., Johansson, L.S., Bjerring, R., Liboriussen, L., Larsen, S.E., Landkildehus, F., Egemose, S., Meerhoff, M., 2012. Advances in ecological research. In: Woodward, G., Jacob, U., Ogorman, E.J. (Eds.), Global Change in Multispecies Systems, Pt 2, vol. 47, pp. 411-488.

Li, H., Pan, G., 2015. Simultaneous removal of harmful algal blooms and microcystins using microorganism- and Chitosan-modified local soil. Environ. Sci. Technol. 49 (10), 6249-6256.

Li, J., Jiao, S., Zhong, L., Pan, J., Ma, Q., 2013. Optimizing coagulation and flocculation process for kaolinite suspension with chitosan. Colloids Surfaces A Physicochem. Eng. Aspects 428, 100-110.

Li, L., Pan, G., 2013. A universal method for flocculating harmful algal blooms in Marine and fresh waters using modified sand. Environ. Sci. Technol. 47 (9), 4555-4562.

Li, L., Zhang, H., Pan, G., 2015. Influence of zeta potential on the flocculation of cyanobacteria cells using chitosan modified soil. J. Environ. Sci. 28, 47-53.

Ng, M., Liana, A.E., Liu, S., Lim, M., Chow, C.W.K., Wang, D.S., Drikas, M., Amal, R., 2012. Preparation and characterisation of new-polyaluminum chloride-chitosan composite coagulant. Water Res. 46 (15), 4614-4620.

Pan, G., Chen, J., Anderson, D.M., 2011a. Modified local sands for the mitigation of harmful algal blooms. Harmful Algae 10 (4), 381-387.

Pan, G., Dai, L., Li, L., He, L., Li, H., Bi, L., Gulati, R.D., 2012. Reducing the recruitment of sedimented algae and nutrient release into the overlying water using modified Soil/Sand flocculation-Capping in eutrophic lakes. Environ. Sci. Technol. 46 (9), 5077-5084.

Pan, G., Yang, B., Wang, D., Chen, H., Tian, B.-h., Zhang, M.-l., Yuan, X.-z., Chen, J., 2011b. In-lake algal bloom removal and submerged vegetation restoration using modified local soils. Ecol. Eng. 37 (2), 302-308.

Paul, W.J., Hamilton, D.P., Gibbs, M.M., 2008. Low-dose alum application trialled as a management tool for internal nutrient loads in Lake Okaro, New Zealand. N. Z. J. Mar. Freshw. Res. 42 (2), 207-217.

Pei, H.Y., Ma, C.X., Hu, W.R., Sun, F., 2014. The behaviors of Microcystis aeruginosa cells and extracellular microcystins during chitosan flocculation and flocs storage processes. Bioresour. Technol. 151, 314-322.

Shi, W.Q., Tan, W.Q., Wang, L.J., Pan, G., 2016. Removal of Microcystis Aeruginosa using cationic starch modified soils. Water Res. 97, 19-25. http://dx.doi.org/ 10.1016/j.watres.2015.06.029.

Sondergaard, M., Wolter, K.D., Ripl, W., 2002. Chemical Treatment of Water and Sediments with Special Reference to Lakes. In: Handbook of Ecological Restoration, vol. 1, pp. 184-205.

Spears, B.M., Lurling, M., Yasseri, S., Castro-Castellon, A.T., Gibbs, M., Meis, S., McDonald, C. McIntosh, J., Sleep, D., Van Oosterhout, F., 2013a. Lake responses following lanthanum-modified bentonite clay (Phoslock (R)) application: an analysis of water column lanthanum data from 16 case study lakes. Water Res. 47 (15), 5930-5942.

Spears, B.M., et al., 2016. A Meta-analysis of Water Quality and Aquatic Macrophyte Responses in 18 Lakes Treated with Lanthanum Modified Bentonite (Phoslock $\left.^{\circledR}\right)$. Water Res 97, 111-121. http://dx.doi.org/10.1016/j.watres.2015.08.020.

Spears, B.M., Meis, S., Anderson, A., Kellou, M., 2013b. Comparison of phosphorus (P) removal properties of materials proposed for the control of sediment $\mathrm{P}$ release in UK lakes. Sci. Total Environ. 442, 103-110. 
Sun, F., Pei, H.Y., Hu, W.R., Li, X.Q., Ma, C.X., Pei, R.T., 2013. The cell damage of Microcystis aeruginosa in $\mathrm{PACl}$ coagulation and floc storage processes. Sep. Purif. Technol. 115, 123-128.

Thornton, J.A., Harding, W.R., Dent, M., Hart, R.C., Lin, H., Rast, C.L., Rast, W., Ryding, S.-O., Slawski, T.M., 2013. Eutrophication as a 'wicked' problem. Lakes Reserv. Res. Manag. 18 (4), 298-316.

USEPA, 1994. Toxicity Characteristic Leaching Procedure.

Vårum, K.M., Ottøy, M.H., Smidsrød, O., 2001. Acid hydrolysis of chitosans. Carbohydr. Polym. 46 (1), 89-98.

Vanbenschoten, J.E., Edzwald, J.K., 1990. Measuring aluminum during watertreatment-methodology and application. J. Am. Water Works Assoc. 82 (5), $71-78$.

Wang, L., Liang, W.Y., Yu, J., Liang, Z.X., Ruan, L.L., Zhang, Y.C., 2013. Flocculation of microcystis aeruginosa using modified larch tannin. Environ. Sci. Technol. 47 (11), 5771-5777.

Wang, W., Bo, S., Li, S., Qin, W., 1991. Determination of the Mark-Houwink equation for chitosans with different degrees of deacetylation. Int. J. Biol. Macromol. 13 (5), 281-285.

Wang, Y.L., Li, B.Q., Zhou, Y., Jia, D.C., Song, Y., 2011. CS-Fe(II,III) complex as precursor for magnetite nanocrystal. Polym. Adv. Technol. 22 (12), 1681-1684.

Wang, Z.B., Zhang, H.G., Pan, G., 2016. Ecotoxicological assessment of modified soil flocculants for lake restoration using an integrated biotic toxicity index. Water Res. 97, 133-141. http://dx.doi.org/10.1016/j.watres.2015.08.033.

WHO, 2003. Guidelines Safe Recreational Water Environments, vol. 1.

Wiśniewska-Wrona, M., Niekraszewicz, A., Ciechańska, D., Pospieszny, H. Orlikowski, L.B., 2007. Biological properties of chitosan degradation products. Pol. Ch. Soc. Monogr. XII, 149-156.

Wyatt, N.B., Gloe, L.M., Brady, P.V., Hewson, J.C., Grillet, A.M., Hankins, M.G. Pohl, P.I., 2012. Critical conditions for ferric chloride-induced flocculation of freshwater algae. Biotechnol. Bioeng. 109 (2), 493-501.

Yadidia, R., Abeliovich, A., Belfort, G., 1977. Algae removal by high gradient magnetic filtration. Environ. Sci. Technol. 11 (9), 913-916.

Yan, L., Wang, Y.F., Ma, H.Z., Han, Z.P., Zhang, Q., Chen, Y.S., 2012. Feasibility of fly ash-based composite coagulant for coal washing wastewater treatment. J. Hazard. Mater. 203, 221-228.

Zou, H., Pan, G., Chen, H., 2005. Effects of ionic strengthon the flocculation and removal of cyanobaterial cells of Microcystis aeruginosa by Clays. Environ. Sci. 26 (02), 148-151 (in Chinese).

Zou, H., Pan, G., Chen, H., Yuan, X.Z., 2006. Removal of cyanobacterial blooms in Taihu Lake using local soils. II. Effective removal of Microcystis aeruginosa using local soils and sediments modified by chitosan. Environ. Pollut. 141 (2) 201-205. 